\title{
An Economy-Environment Integrate Statistic System
}

\author{
Giani Gradinaru \\ Bucharest Academy of Economic Studies \\ Romania
}

\section{Introduction}

The economy-environment inter-conditioning is so visible that any attempt to fundament this affirmation is useless. The environment furnishes the resources, which represent the nucleus of the supply economic activity. The supply is made for two main reasons: goods and services production and consumption. Both production and consumption create wastes, and these wastes are evacuated in the environment (Fig. 1).

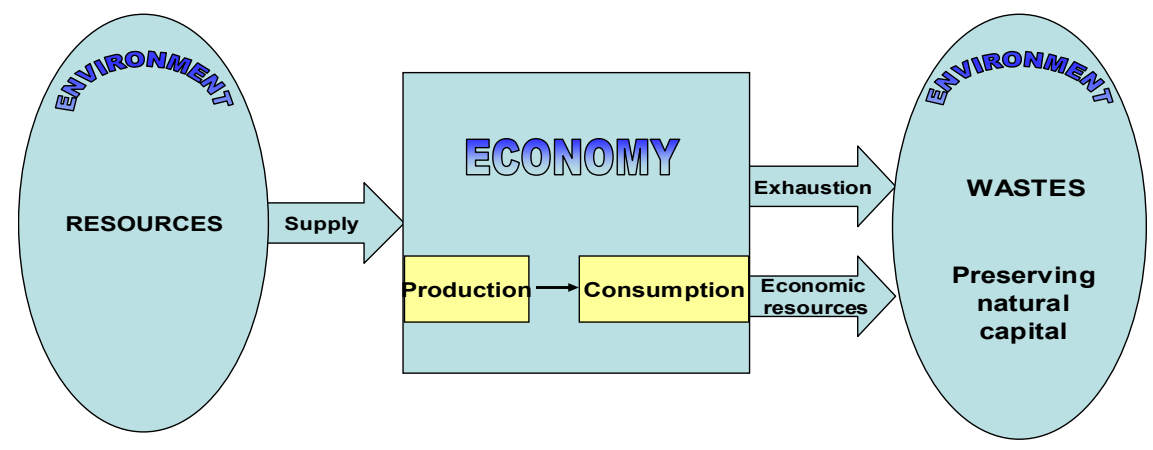

Fig. 1. The economy-environment inter-conditioning

The concept of lasting development doesn't leave any space for a separate discussion on environment economy. The Rio Conference, the 21 Agenda, the Johannesburg summit, scientists' workshops has already established the conceptual basis for creating an environment-economy integrated informational system. No country can be left out because one cannot set boundaries on the environment.

Identifying the information categories relevant for decisions grounding can start the achievement of an informational system concerning lasting development, even before the theoretical and methodological development is fully settled. Thus it can be considered determinant five information categories:

- Highlighting the environment status based on separate environment factors (water, air, soil, biological diversity); 
- Emphasizing the environment pressures based on sectors considered pressure sources;

- $\quad$ Estimating the expenses made to avoid pressures;

- Evaluating the size of environment advantages and damages according to the environment pressures;

- Highlighting the standards, which can regulate the pressure.

The first four information categories are so strongly connected to the evaluation problems, that the only problems that may appear are connected to the data collecting methods and the efforts of collecting and processing. On what concerns standards value, there are understandings which count more or less on scientific appreciation, which sustains a higher level of information quality, also generated by the fact that these are decision elements in solving environment problems. An incomplete and uncertain information may influence the consequences of economic activities such as subsequent development.

Achieving the lasting development objectives on a large scale presumes that economic policies are projected according to environment considerations and to the economic functions of the natural resources. For this, the deciding persons need info concerning economic activities and environment status expressed in natural and monetary units. Such information must be built in a manner, which allows an emphasis of the main problem of the lasting development and the inner-generation equity, keeping the environment health for future generations.

The efficiency of the economic reform policies can be evaluated by comparing the traditional synthetic indicators with the ones resulted from integrating the environment data. A simple comparison of these indicators can supply an adequate understanding for introducing the environment parameters in an economic system, reason for that is necessary the use of economic-mathematical modeling.

Because economic policies must be projected in the light of their impact on the environment, the environment policies must take into consideration the economic implications. This integration became nowadays a basic problem in conceiving environment policies, for which the integrated economy-environment indicators can facilitate a coherent wording.

The standard economic indicators, which describe mainly the financial flows in an economy, supply incomplete information concerning the implications of economic activities on the environment. The economic instruments have different possibilities of comparing their results in time and space, but such methods are not developed for environment. The environment informational instruments are usually based on physical parameters, while the economic informational instruments use both physical and value data. As a result, there are significant deficiencies for the quality level of the indicators which must explain the economy-environment inter-dependence, a fact which imposes developing integrated indicators to express the direct connection between the economic activities and environment, in the direction of lasting development request (Fig. 2). In this direction we can define the following priorities:

- The necessity to develop vertical connections between the economic instruments for macro and microeconomic level, respectively between the individual environment indicators (microeconomic level) and the synthesis indicators (macroeconomic level); 
- The necessity to develop horizontal relations between the economic and environmental instruments for sector or regional level, respectively including the environment indicators in an economic decisional process;

- The necessity to represent the environment indicators in time dimension, respectively building chronological series for most part of the indicators expressing the economic and environmental performances.

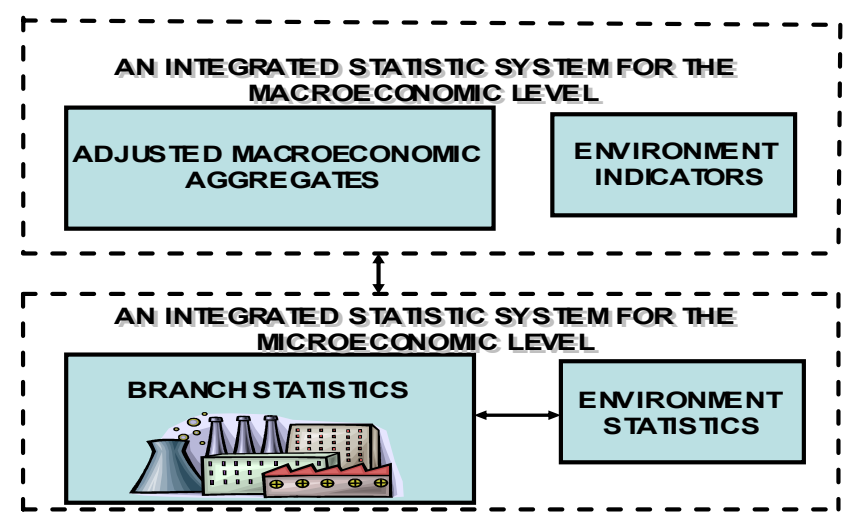

Fig. 2. The economy-environment integration for informational

\section{Environment statistic subjects and variables}

The statistic base for the economy-environment integrated statistic analysis is complex and perfectible, and this improvement can be achieved gradually. A comprehensive description of the environment requires the integration of a large number of data sources in order to reach a more complete image of the pressure exerted on the environment, of its quality state and of the efforts made to protect the environment. In our country, the present state of these data sources is situated at very low quality level, representing the main obstacle in developing the environment statistic system. The primary data for building the environment statistic-economical analysis system can be improved by developing statistic registers, national accounting revision, doing new statistic researches and improving the existing ones.

Developing the system of environment statistic subjects and variables must be preceded by a clarification of aspect concerning:

- The universal statistic language, the coherence of statistic description being given by the rigorous classification of the statistic subjects, a classification which allows comparison between the information referring to different time periods or different geographical areas (in order to be efficient a statistic language for the economy-environment relation must be systematically developed, so different types of standards to become compatible and establish relations between different information);

- Developing work programs for data gathering and dissemination for subjects such as: emissions, water prevailing and use, waste flow, chemical use, environment protection expenses, available sector statistics for description of environment impact activities etc.; 
- Attracting in the environment statistic circuit of those data corresponding to administrative sources, for filling the data fond necessary to comprehensive reflection of the environment problems such as: climate change, air acidification and pollution, exhausting natural resources, exhausting and polluting water resources, urban environment deterioration and waste flow;

- Adopting the European definitions, classifications and unique harmonized naming by the Governmental and non-governmental institutions;

- $\quad$ Projecting and implementing a coherent survey system which would use questionnaires that cover essential domains of the environment statistics;

- Building statistics based on calculus models for those domains, which cannot be informational, covered by statistic surveys or administrative data, such as the case of greenhouse effect gases, chemicals diminishing the ozone layer etc.

When developing the set of environment statistic variables, the present international achievements indicate a preference for combing the environment elements based approach with the one referring to the pressure-status-response and few components from the resource management approach. In Romania, the National Statistic Institute maintains the same conception, a reason for which we would restore a possible draft for developing the environment statistic system of subjects and variables, a draft achieved by combining the three types of approaches mentioned earlier (Fig. 3).

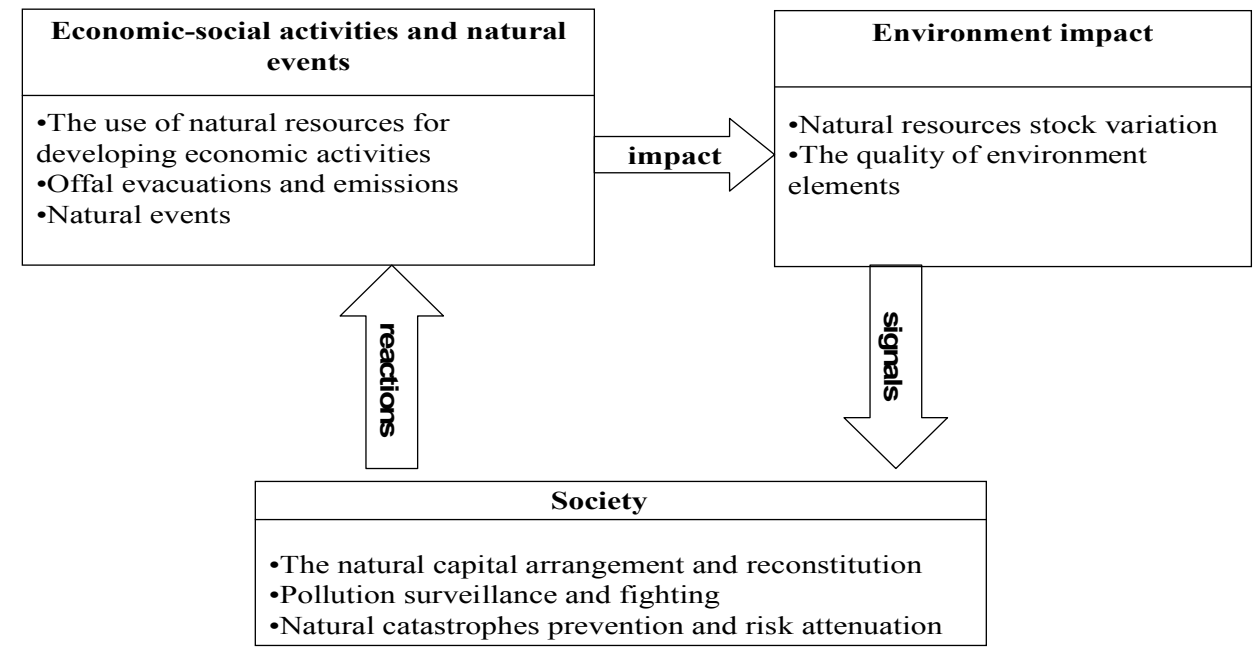

Fig. 3. A draft for developing the environment statistic subjects

\subsection{Natural resources use for developing economic activities}

Natural resources consumption represents an activity with environment impact generated by the impossibility to restore the consumed resource in a short period. The economic activities with potential environment impact are agriculture, forestry, hunting, fishing, and mining and the extractive industry, energy production and consumption, water use, soil use and landscape transformation. 
Agriculture may have environmental incidence by raising the production determined by a growth in cultivated surface or animal effective, either by a growth in agricultural efficiency (Fig. 4.).

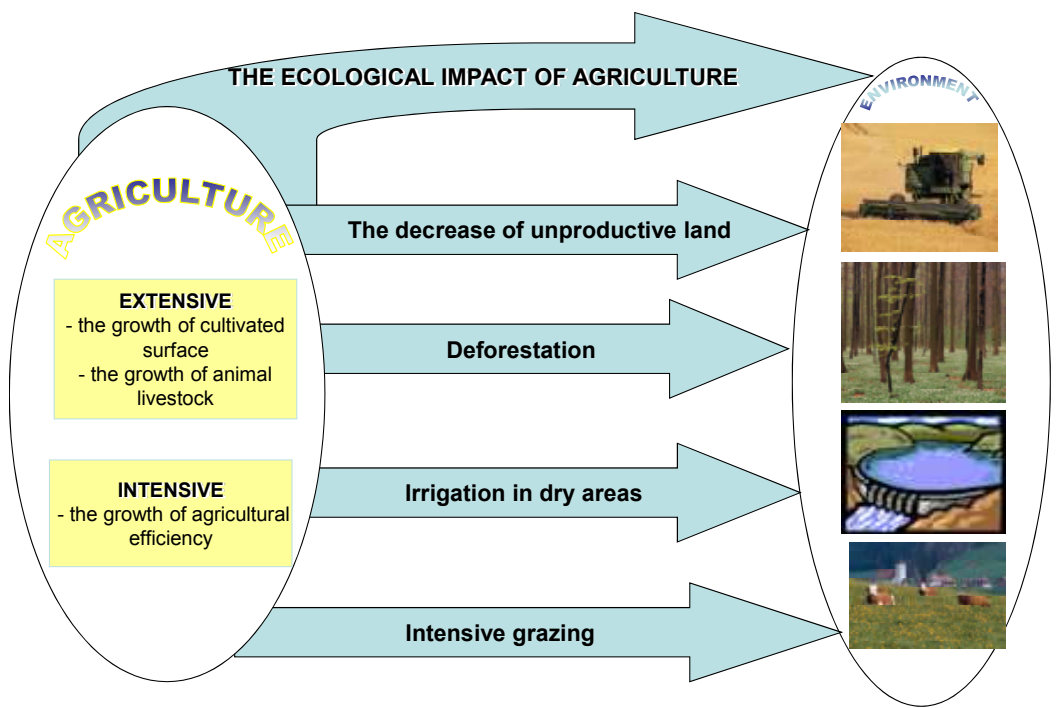

Fig. 4. The ecological impact of agriculture

The statistic subjects which reflect the connection between agriculture and environment refer to a growth of agricultural production (either by extensive agriculture, or intensive) and emphasizing the place of agriculture in the market economy (table 1).

\begin{tabular}{|l|l|}
\hline Agriculture & Statistic variables \\
\hline \multirow{3}{*}{$\begin{array}{l}\text { Extensive } \\
\text { agriculture }\end{array}$} & $\begin{array}{l}\text { Cultivated surfaces and the production achieved grouped by types of } \\
\text { culture }\end{array}$ \\
\cline { 2 - 2 } & The animal effective and their density by animal species \\
\hline \multirow{4}{*}{$\begin{array}{l}\text { Intensive } \\
\text { agriculture }\end{array}$} & $\begin{array}{l}\text { The applied quantity of fertilizers and the fertilized surfaces by types of } \\
\text { fertilizer substances used }\end{array}$ \\
\cline { 2 - 2 } & The fodder quantities consumed by animals grouped by type of fodder \\
\cline { 2 - 2 } & The agriculture energy consumption by types of energy \\
\cline { 2 - 2 } $\begin{array}{l}\text { The place of } \\
\text { agriculture in } \\
\text { the market } \\
\text { economy }\end{array}$ & $\begin{array}{l}\text { Agricultural practices based on types of works } \\
\text { value) }\end{array}$ \\
\cline { 2 - 2 } & The inputs volume (physical and value) \\
\cline { 2 - 2 } & The gross capital formation on types of agricultural exploitation \\
\cline { 2 - 2 } & The exported volume by different types of products (physical and value) \\
\cline { 2 - 2 } & The volume destined for self-consumer \\
\hline
\end{tabular}

Table 1. The statistic variables for highlighting the agriculture-environment relation 
The forestry activity has a negative impact on the environment because of forest commercial exploitation, but also a positive impact because of forestation interventions (Fig. 5.).

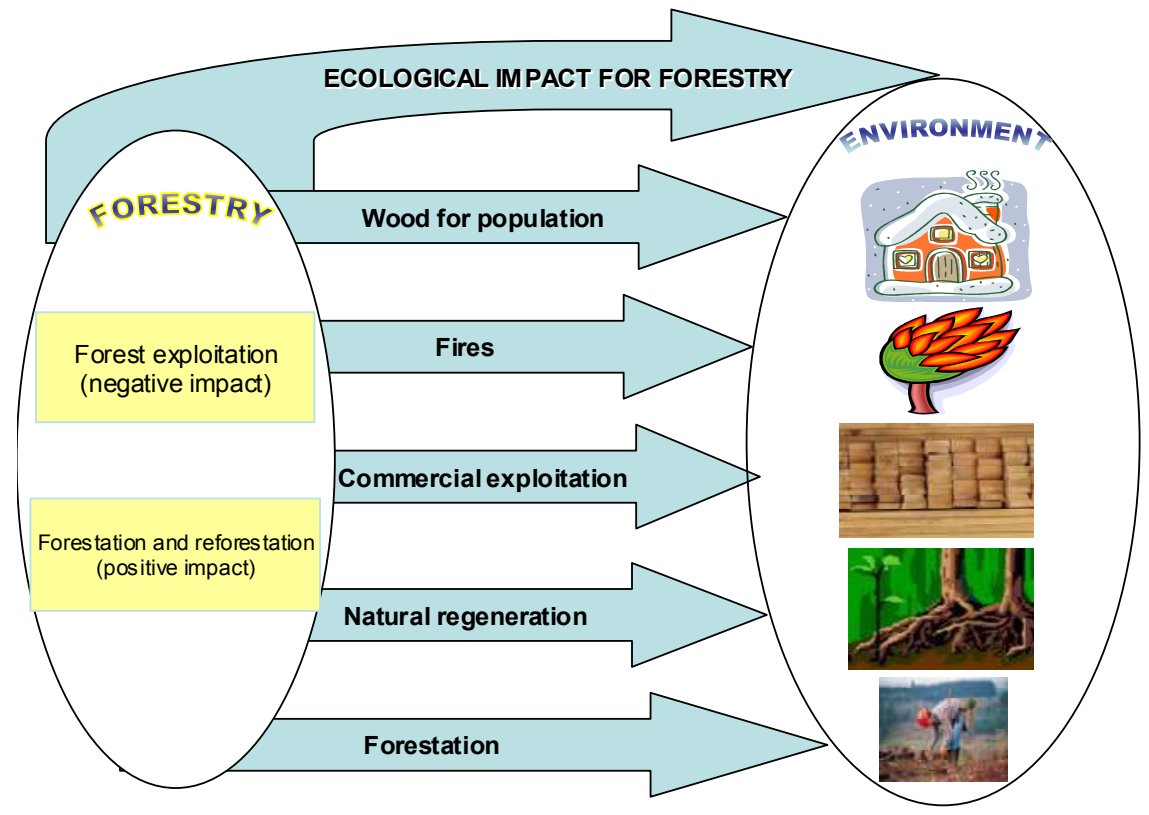

Fig. 5. The ecological impact of forestry

The statistic subjects identified by forestry activity and forest exploitation, connected to environment components consider the commercial exploitation of the forest; wood samples for population, natural loss (fires, diseases, pollution), natural regeneration and forestation (table 2.).

\begin{tabular}{|l|l|}
\hline Forestry & Statistic variables \\
\hline \multirow{2}{*}{$\begin{array}{l}\text { the commercial exploitation of } \\
\text { the forest }\end{array}$} & The exploited timber quantity by types of species \\
\cline { 2 - 2 } & The primary timber production \\
\cline { 2 - 2 } & Timber exports without any transformation \\
\hline \multirow{2}{*}{ natural loss } & Losses on types of essences \\
\cline { 2 - 2 } & The deforestation on types of essences \\
\hline \multirow{3}{*}{ regeneration and forestation } & The annual timber growth on wood species \\
\cline { 2 - 2 } & Naturally regenerated surfaces \\
\cline { 2 - 2 } & Forestation surfaces \\
\hline
\end{tabular}

Table 2. Statistic variables for highlighting the forestry-environment relation

The hunting activity may also influence the environment by destroying fauna habitats as a result of over exploitation or by deliberate destruction of the injurious species (Fig. 6.).

The statistic variables that reflect the connection between hunting and environment refer to the hunting harvest and the economic contribution of this activity (table 3.). 


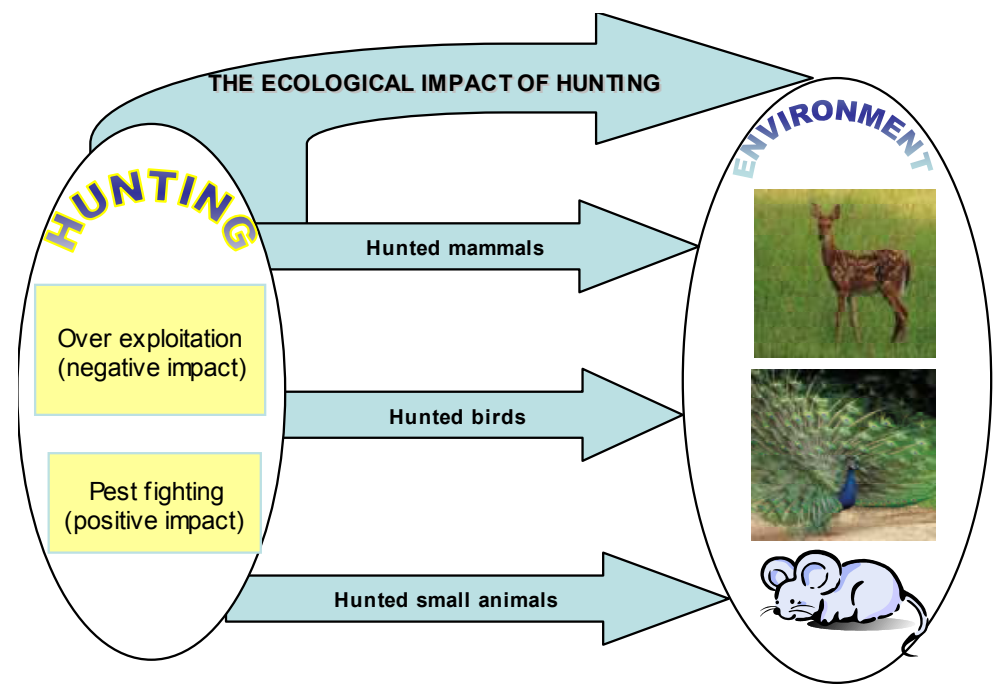

Fig. 6. The ecological impact of hunting

\begin{tabular}{|l|l|}
\hline Hunting & Statistic variables \\
\hline \multirow{4}{*}{$\begin{array}{l}\text { The economic } \\
\text { Contribution }\end{array}$} & The hunted mammals effective, on species \\
\cline { 2 - 2 } & Small animals hunted effective, on species \\
\cline { 2 - 2 } & Number of hunted birds, on species \\
\cline { 2 - 2 } & $\begin{array}{l}\text { The income selling specific equipment, hunting permits and the use of } \\
\text { tourist infra structure, on types of products }\end{array}$ \\
\cline { 2 - 2 } & The export on types of products \\
\hline
\end{tabular}

Table 3 . The statistic variables for highlighting the hunting-environment relation

The fishing activity can create serious environmental damage by over exploitation and the use of "brutal" fishing methods (Fig. 7.).

In a similar way to the hunting activity, in the case of fishing the main statistic subjects which can be developed refer to the fishing capture and the economic contribution of this activity (table 4.).

The impact of fishing and the extracting industry on the environment can be analyzed by referring to the following statistic subjects, associated to the cycles of mining exploitation (Fig. 8.).

\begin{tabular}{|l|l|}
\hline Fishing & Statistic variables \\
\hline \multirow{3}{*}{ Fish capture } & The fish quantity harvested from the sea, on species \\
\cline { 2 - 2 } & The fish quantity harvested from internal waters, on species \\
\cline { 2 - 2 } & The fish quantity harvested by sporting fishing, on species \\
\hline Economic contribution & The export of fish products, on species \\
\hline
\end{tabular}

Table 4 . The statistic variables for highlighting the fishing-environment relation 


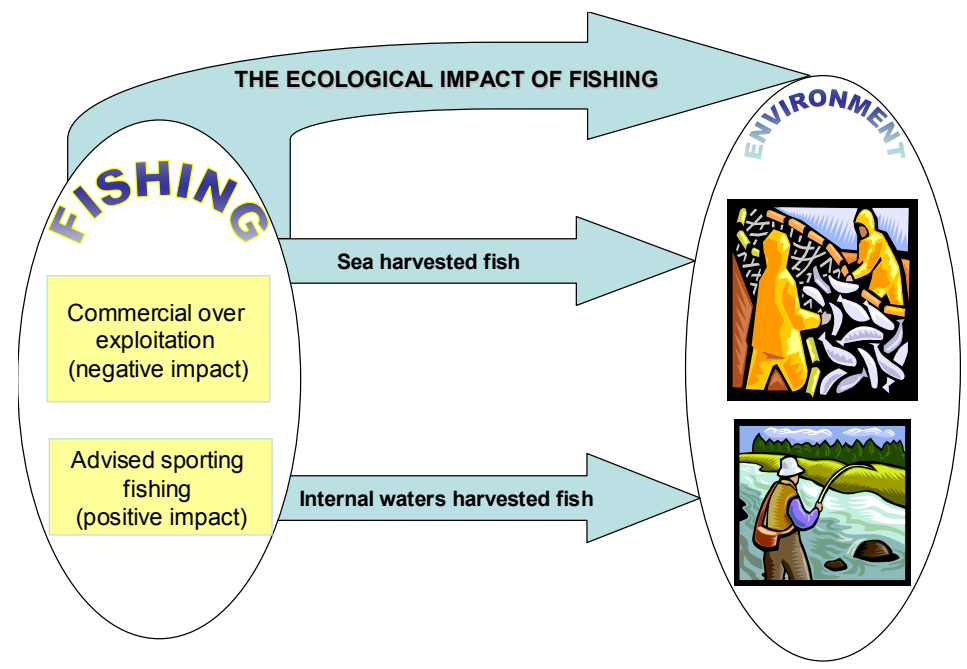

Fig. 7. The ecological impact of fishing

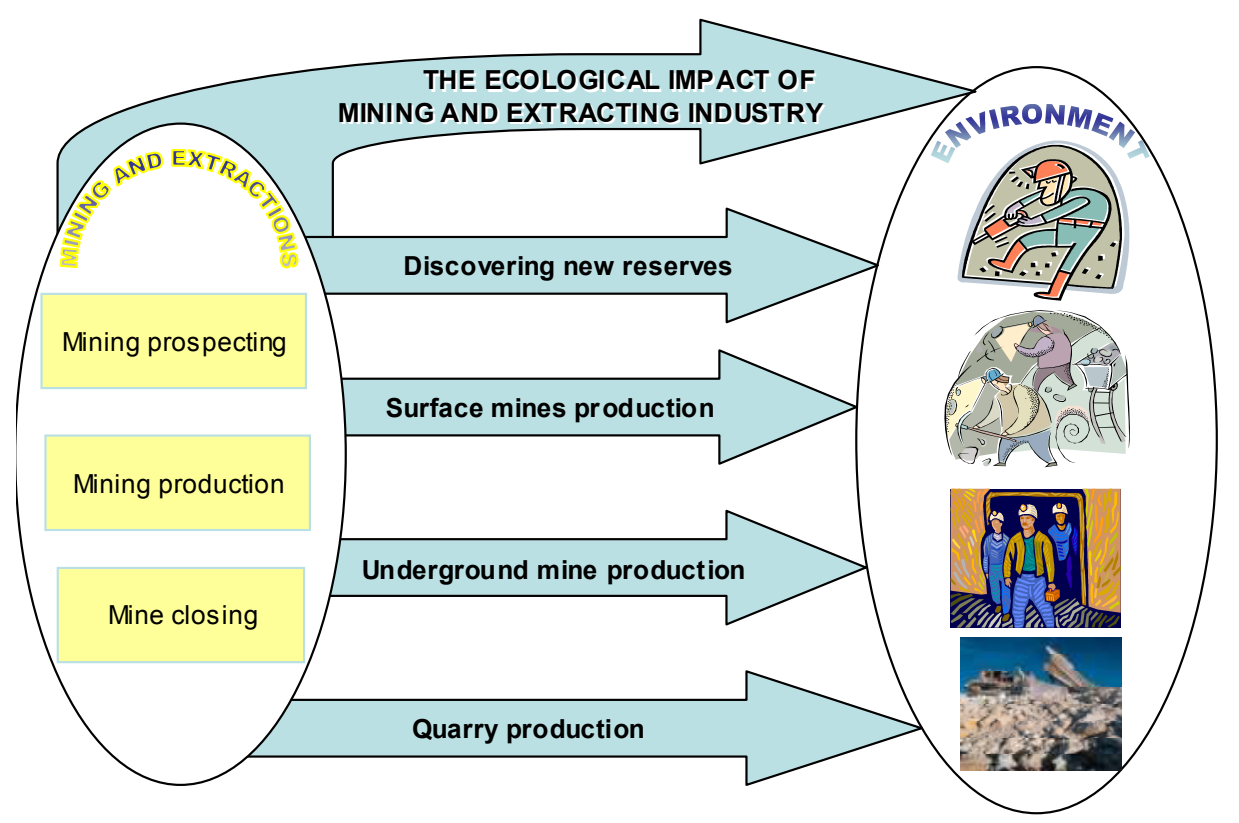

Fig. 8. The ecological impact of mining and extracting industry

The statistic variables, which can be used to analyze the ecological impact of mining and the extracting industry, are presented in table 5.

The energy production and consumption have significant environment impact from the consumer perspective, and also from the pollution perspective. (Fig. 9.). 


\begin{tabular}{|l|l|}
\hline Mining and extracting industry & Statistic variables \\
\hline $\begin{array}{l}\text { Mining exploitation by mine } \\
\text { prospecting }\end{array}$ & The newly discovered reserves by mineral type \\
\hline \multirow{3}{*}{ Mining production } & The underground mines production by mineral type \\
\cline { 2 - 2 } & The surface mines production by mineral type \\
\cline { 2 - 2 } & The quarry production by mineral type \\
\hline Mine closing & The number of closed mines by mineral type \\
\hline \multirow{2}{*}{$\begin{array}{l}\text { The role of mineral resources in } \\
\text { the }\end{array}$} & The value of mining production by mineral type \\
\cline { 2 - 2 } economy & The gross mineral export by mineral type \\
\cline { 2 - 2 } & $\begin{array}{l}\text { The metallurgy consumed minerals by procedure } \\
\text { type }\end{array}$ \\
\hline
\end{tabular}

Table 5. The statistic variables for highlighting the mining, extracting industry- environment relation

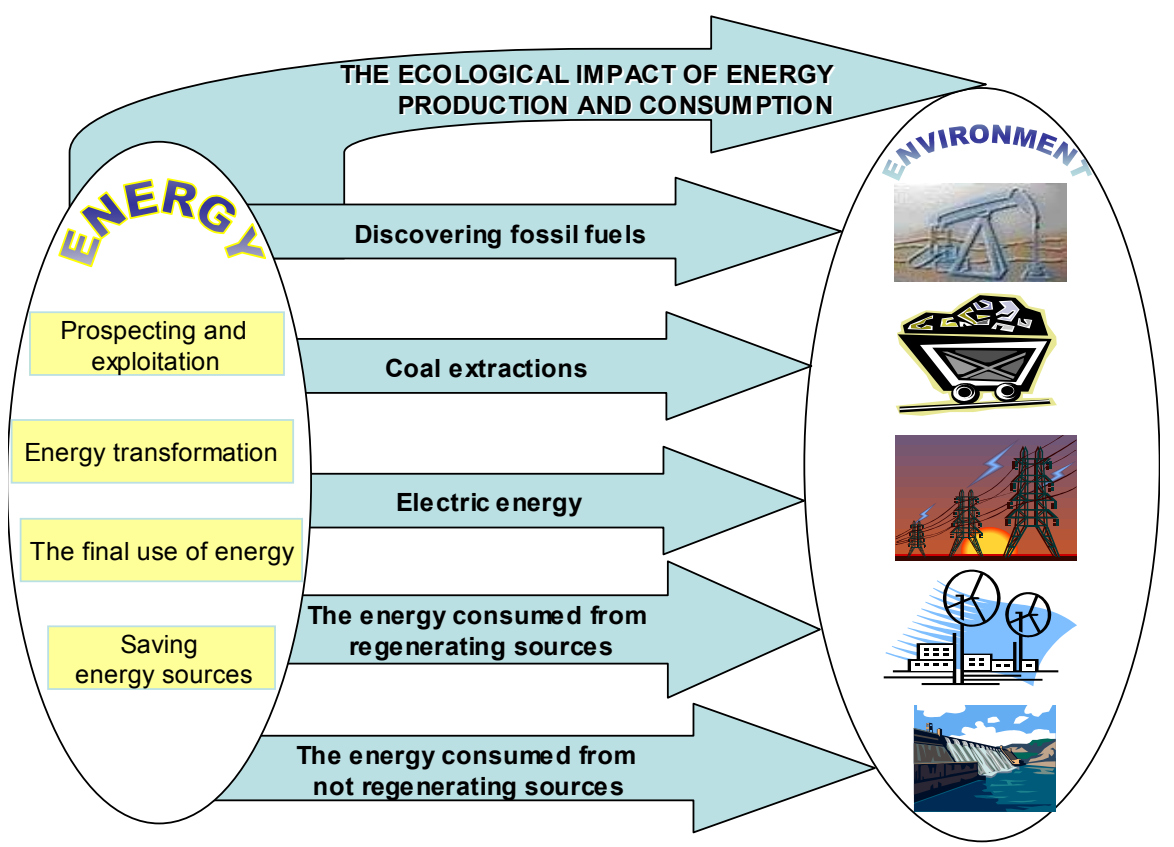

Fig. 9. The ecological impact of energy production and consumption

Table 6 presents the statistic subjects and variables highlighted by the analysis of the impact of energy production and consumption activities on the environment.

The water use is the origin of many environmental problems, especially when the drawings from water bearing formations are made in a rhythm superior to the supply one. In dry areas, the drawing from watercourses may reduce the water quantity at the disposal of downstream users. Another subject of the preoccupation is constituted by the quality of residual water, when it's disposed in water streams, lakes or sea. The statistic subjects and variables, which create the framework of the statistic-economic analysis of water use, are given in table 7. 


\begin{tabular}{|c|c|}
\hline $\begin{array}{l}\text { Energy } \\
\text { production } \\
\text { and } \\
\text { consumption }\end{array}$ & Statistic variables \\
\hline \multirow{3}{*}{$\begin{array}{l}\text { Prospecting } \\
\text { and } \\
\text { exploitation } \\
\text { activities }\end{array}$} & $\begin{array}{l}\text { The prospecting number (oil resources, natural gas and coal, discovering } \\
\text { other fossil fuel prospecting ), by resource type }\end{array}$ \\
\hline & The volume of natural gas and oil extraction \\
\hline & The coal volume extraction \\
\hline \multirow{4}{*}{$\begin{array}{l}\text { Energy } \\
\text { transforming } \\
\text { activities }\end{array}$} & The quantity of fossil fuel used to produce thermal energy, by fuel type \\
\hline & The electricity production based on fossil fuels, by fuel type \\
\hline & The electricity production based on classic systems, by types of sources \\
\hline & $\begin{array}{l}\text { The electricity and thermal energy production from unconventional, by } \\
\text { sources type }\end{array}$ \\
\hline \multirow{2}{*}{$\begin{array}{l}\text { Energy final } \\
\text { use activities }\end{array}$} & The intermediate energy consumption by activity type or industries \\
\hline & The energy final consumption by activity type \\
\hline \multirow{3}{*}{$\begin{array}{l}\text { Energy } \\
\text { administration }\end{array}$} & The energy consumption/ habitant and by energy type \\
\hline & $\begin{array}{l}\text { The proportion of energy consumption from renewable or non- } \\
\text { renewable sources }\end{array}$ \\
\hline & The imported or exported energy by energy type \\
\hline
\end{tabular}

Table 6. The statistic variables for highlighting the relation: energy production and consumption - environment

\begin{tabular}{|l|l|}
\hline Water use & Statistic variables \\
\hline \multirow{2}{*}{ Water drawing } & Water drawn from surface sources, by types of sources \\
\cline { 2 - 2 } & Water drawn from underground sources \\
\hline \multirow{4}{*}{ Water use } & The water quantity used in agriculture \\
\cline { 2 - 2 } & The water quantity used in industry, by activity type \\
\cline { 2 - 2 } & The water quantity used for energy production \\
\cline { 2 - 2 } & The water quantity consumed by households \\
\hline
\end{tabular}

Table 7. The statistic subjects and variables for the water use analysis

The set of statistic subjects and variables which can be used in the soil use and landscape transformation analysis, as distinct aspects of the natural resources use with the purpose of economic activity development, is given in table 8 .

\begin{tabular}{|l|l|}
\hline $\begin{array}{l}\text { Soil use and landscape } \\
\text { transformation }\end{array}$ & Statistic variables \\
\hline $\begin{array}{l}\text { Changing the } \\
\text { destination }\end{array}$ & Changes in soil use between activity sectors, by soil use form \\
\hline \multirow{5}{*}{$\begin{array}{l}\text { Environment } \\
\text { reorganization }\end{array}$} & Changes in soil use inside the economic sector, by soil use form \\
\cline { 2 - 2 } & $\begin{array}{l}\text { The transport network by transport type } \\
\text { lakes, canals }\end{array}$ \\
\cline { 2 - 2 } & Creating residential and industrial areas \\
\cline { 2 - 2 } & $\begin{array}{l}\text { Achieving substructures for: mining, forest exploitation and } \\
\text { commerce }\end{array}$ \\
\hline
\end{tabular}

Table 8. The statistic subjects and variables specific to the economic activity which imply soil use and landscape transformation 


\subsection{Waste emission and exhaustion}

The statistic analysis of waste emission and exhaustion resulted from economic- social activity consider the air polluting substances emission, the exhaustion of polluting substances in water and generating wastes. The statistic variables used in such analysis are presented in table 9 .

\begin{tabular}{|c|c|}
\hline $\begin{array}{l}\text { Waste emission and } \\
\text { exhaustion }\end{array}$ & Statistic variables \\
\hline $\begin{array}{l}\text { Polluting substances } \\
\text { air emission }\end{array}$ & $\begin{array}{l}\text { The emitted quantity of polluting substances (nitrogen oxides, } \\
\text { carbon oxides, ammonia, organic and inorganic compounds, } \\
\text { heavy metals, suspension powders) by type of polluting agents } \\
\text { and activities }\end{array}$ \\
\hline \multirow{4}{*}{$\begin{array}{l}\text { Polluting substances } \\
\text { water exhaustion }\end{array}$} & $\begin{array}{l}\text { The volume of residual water from the public sewage system, by } \\
\text { type of polluting agents and hydrographic basins }\end{array}$ \\
\hline & $\begin{array}{l}\text { The volume of industrial residual water, by type of polluting } \\
\text { agents and hydrographic basins }\end{array}$ \\
\hline & $\begin{array}{l}\text { The quantity of polluting substances resulted from agricultural } \\
\text { practices (diffuse pollution due to agriculture) }\end{array}$ \\
\hline & $\begin{array}{l}\text { The quantity of polluting substances in the rain (diffuse pollution } \\
\text { due to acid rainfall) }\end{array}$ \\
\hline \multirow[b]{2}{*}{ The amount of wastes } & Soil, waters, air waste evacuations \\
\hline & $\begin{array}{l}\text { Other variables can be developed in concordance with the waste } \\
\text { classification }\end{array}$ \\
\hline
\end{tabular}

Table 9. The statistic variables for highlighting waste emission and exhaustion

\subsection{Natural events}

These statistic subjects contain variables referring to natural phenomena, which can affect human population production, consumption and welfare. There is a synergetic effect between the natural phenomena and the impact of human activity on the environment. For example, a poor land use during drought may stimulate a deserting phenomenon; building human settlements in vulnerable or seismic areas cause destruction and human lives loss (Fig. 10.).

The variables, which come out of, figure 10 describes the size and intensity of natural events, classified by meteorological geological or biological origin (table 10.).

\begin{tabular}{|l|l|}
\hline Natural events & Statistic variables \\
\hline \multirow{3}{*}{ Meteorological risks } & The rainfall volume and its variation according to the average \\
\cline { 2 - 2 } & $\begin{array}{l}\text { The temperature and its variation according to the average } \\
\text { temperature }\end{array}$ \\
\hline \multirow{2}{*}{ Geological risks } & The number of earthquakes \\
\cline { 2 - 2 } & The landslides number \\
\hline \multirow{2}{*}{ Biological risks } & The insect infested surfaces \\
\cline { 2 - 2 } & The number of epidemics \\
\hline
\end{tabular}

Table 10. The specific statistic variables for describing the natural events 


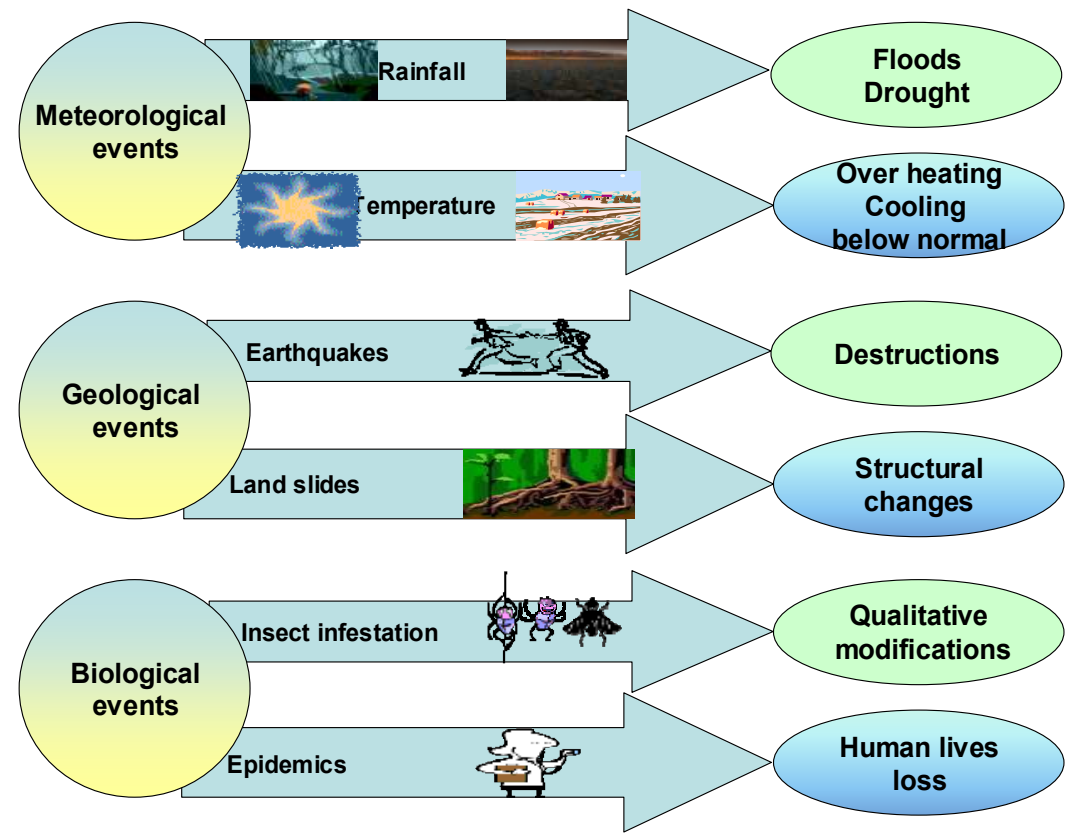

Fig. 10. Natural events

\subsection{The natural resources stock variation}

The statistics subjects included in this category devolve from the informational system, which considers the lasting resource management. The emphasis is put on growth or reduction of biological resources stock and of cyclic resources (water, soil and minerals). From the environment's point of view, a reduction of the biological resources stock happens when the exploitation exceeds the natural regeneration rhythm (table 11.).

\begin{tabular}{|l|l|}
\hline Environment elements & Statistic variables \\
\hline \multirow{5}{*}{ Soil/subsoil } & The net variation of land surfaces \\
\cline { 2 - 2 } & The net variation of annual cultures biological mass \\
\cline { 2 - 2 } & The livestock net variation \\
\cline { 2 - 2 } & The net variation of forests \\
\cline { 2 - 2 } & The variation of forest biological mass \\
\cline { 2 - 2 } & The losses of productive soil due to land use changes \\
\cline { 2 - 2 } & The losses of productive soil due to corrosion \\
\cline { 2 - 2 } & The initial reserve of mineral resources by mineral type \\
\cline { 2 - 2 } & The annual production of mineral reserves by mineral type \\
\hline \multirow{5}{*}{ Water } & The variation of the fish population \\
\cline { 2 - 2 } & The level variation for surface water \\
\cline { 2 - 2 } & The modification of the average flow of water streams \\
\cline { 2 - 2 } & The variation of the lakes stocking capacity \\
\hline
\end{tabular}

Table 11. The statistic variables for the analysis of natural resources stock variation 


\subsection{The environment elements quality}

The level of air, soil and water quality is generally compared to standard quality norms. The statistic variables may express in terms of variation and frequency, the exceeding of admitted standards and the quality degree of each environment element (table 12.). The air quality is mainly determined by environmental pollutant concentrations. In this direction, in order to control the polluting chain and fight its effects must be used in all of the pollutant production and transmission stages the same concepts, definitions and classifications. The notion of water quality is more complex than the one of air quality, because quality parameters depend besides the pollution agents on the water uses. Establishing the statistic variables referring to water quality is necessary because of the preoccupations concerning the contamination of the hydrographic network, due to pollutant evacuations from industrial, agricultural and human settlements units. Soil quality influences the productivity of biological systems, and their degradation reduces the production of biological mass and the capacity to produce services. Natural factors, but also agriculture practices determine the variation in soil quality. In this manner, soil degradation can be connected with wrong work and use practices for agricultural crops, but also with land improvement activities and excessive use of agrochemical products. Also, a certain state of soil quality contributes to acid deposits resulted from atmospheric pollution, the humus loss as a result of chemical fertilizers applications, soil compaction due to agricultural machines use.

\begin{tabular}{|l|l|}
\hline $\begin{array}{l}\text { Environment } \\
\text { element }\end{array}$ & Statistic variables \\
\hline \multirow{5}{*}{ Air } & $\begin{array}{l}\text { The maximum effective concentration of pollutants by type of pollutant } \\
\text { agents }\end{array}$ \\
\cline { 2 - 3 } & $\begin{array}{l}\text { The average monthly/annual pollutant concentration by type of } \\
\text { polluting agents }\end{array}$ \\
\cline { 2 - 3 } & The frequency of exceeding the maximum admitted concentration \\
\hline \multirow{5}{*}{ Water } & The physical and chemical properties of used waters \\
\cline { 2 - 3 } & The chemical substances concentrations \\
\cline { 2 - 3 } & $\begin{array}{l}\text { The organic matter concentrations expressed by COD (Chemical oxygen } \\
\text { demand - the oxygen quantity took from the water organic matter, used } \\
\text { as a measurement unit for organic matter in domestic waters) }\end{array}$ \\
\cline { 2 - 3 } Soil & The river length by quality classes \\
\hline \multirow{5}{*}{ Deserted surface } \\
\cline { 2 - 2 } & Eroded surface \\
\cline { 2 - 2 } & Toxic substances contaminated surface \\
\cline { 2 - 2 } & The acid deposits surface \\
\cline { 2 - 2 } & The surface of irrigation degraded soil \\
\hline
\end{tabular}

Table 12. The statistic variables for the emphasis of environment elements quality

\subsection{The arrangement and reconstitution of natural capital}

The improvement of resource consumption in the classical meaning, considers an economic productivity maximization of natural resources for the growth of production units which use these resources, such as: agriculture, forest exploitation, fishing and the extracting industries. A statistic expression for the arrangement and natural capital reconstitution can be achieved with the help of following statistic variables highlighted in table 13. 


\begin{tabular}{|l|l|}
\hline $\begin{array}{l}\text { The arrangement and } \\
\text { reconstitution of natural capital }\end{array}$ & Statistic variables \\
\hline \multirow{4}{*}{$\begin{array}{l}\text { Nature protection and } \\
\text { conservation }\end{array}$} & The national parks network \\
\cline { 2 - 2 } & Protected areas \\
\cline { 2 - 2 } & Protected fauna \\
\cline { 2 - 2 } & $\begin{array}{l}\text { Public expenses for arranging and restoring natural } \\
\text { resources }\end{array}$ \\
\cline { 2 - 2 } & $\begin{array}{l}\text { The personnel engaged in protecting and conserving } \\
\text { nature }\end{array}$ \\
\hline \multirow{2}{*}{$\begin{array}{l}\text { Reconstitution of degraded } \\
\text { environment }\end{array}$} & Restored agricultural land \\
\cline { 2 - 2 } & Trees cultivated land \\
\cline { 2 - 2 } & Protected species of flora and fauna \\
\hline
\end{tabular}

Table 13. The statistic variables for describing the arrangement and reconstitution of natural capital

\subsection{Pollution supervision and control}

There are more categories of statistic variables, which can describe the activities of pollution supervision and control (table 14.).

\begin{tabular}{|c|c|}
\hline $\begin{array}{l}\text { Pollution supervision } \\
\text { and control }\end{array}$ & Statistic variables \\
\hline \multirow{2}{*}{$\begin{array}{l}\text { Pollution research and } \\
\text { environment supervision }\end{array}$} & The number of researches concerning pollution \\
\hline & The number of air or water quality supervision stations \\
\hline \multirow{2}{*}{$\begin{array}{l}\text { Environment restoring and } \\
\text { pollution fighting }\end{array}$} & Pollution fight by pollutant type and ecosystem \\
\hline & Restoring operation by ecosystem and pollutant type \\
\hline \multirow{4}{*}{$\begin{array}{l}\text { The means to fight } \\
\text { pollution }\end{array}$} & $\begin{array}{l}\text { The number of water treating stations by type of treatment } \\
\text { and hydrographic basins }\end{array}$ \\
\hline & The mud quantity evacuated by hydrographic basin type \\
\hline & The quantity of dangerous waste treated \\
\hline & Public funds allocation for the enterprises pollution fight \\
\hline \multirow{5}{*}{$\begin{array}{l}\text { Actions started by } \\
\text { enterprises }\end{array}$} & The volume of cleaned residual water \\
\hline & The necessary cost for managing dangerous waste \\
\hline & Waste recycling \\
\hline & Investments for environment protection techniques \\
\hline & $\begin{array}{l}\text { The costs engaged for producing consumer goods which } \\
\text { don't endanger the environment }\end{array}$ \\
\hline \multirow{6}{*}{ The households' reactions } & The modifications in the expenses structure \\
\hline & Households' waste recycling \\
\hline & Buying products with low environment impact \\
\hline & $\begin{array}{l}\text { The consumption modalities by type of consumer } \\
\text { (Choosing lead free gas, using paper wrappings, choosing } \\
\text { the size of the vehicle, etc.) }\end{array}$ \\
\hline & Recycling materials \\
\hline & $\begin{array}{l}\text { The population behavior on what concerns the } \\
\text { participation to the recycling process }\end{array}$ \\
\hline
\end{tabular}

Table 14. The statistic variables for the description of the pollution supervision and control 


\subsection{Preventing natural catastrophes an risk attenuation}

In front of natural forces, the reaction may be scientific, technical, biological, administrative and humanitarian. The variables presented in this category (table 15.) describe the measures took in order to prevent floods, the operation of catastrophes surveillance and foreseeing, emergency measures for reducing their effects (meaning evacuating the population, etc.).

\begin{tabular}{|l|l|}
\hline Types of activities & Statistic variables \\
\hline \multirow{3}{*}{ Prevention } & The number of researches by activity type \\
\cline { 2 - 2 } & The physical substructure for natural catastrophe protection \\
\cline { 2 - 2 } & Administrative regulations by regulation type \\
\hline Control & Biological activities \\
\hline
\end{tabular}

Table 15. The statistic variables for emphasizing the preventing actions for natural catastrophes and risk attenuation

\section{Conclusion}

The economy-environment integrated statistic analysis can be applied in different stages of the decisional process, such as: identifying environment priorities, identifying the pressure points, projecting environment policy, evaluating the policy's effects. The data can be used to monitor the effects of environment policies in the terms of public and private commercial activities, as well as in terms of positive or negative sector effects induced by different sectors.

\section{Acknowledgment}

This research was supported by Human Recourses Program, Grant no. TE_336/2010, (agreement no. 45/03.08.2010), financed by National University Research Council (CNCSISUEFISCDI).

\section{References}

Bran, F. (2002). Componenta ecologică a deciziilor de dezvoltare economică, ASE Printing House, Bucharest.

Bryant, D., Nielsen, D., Tangley, L. (1997), The last frontier forests: ecosystems and economies on the edge, World Resources Institute, Washington DC.

Cox, S., Searle, B. (2009), The sate of ecosystem services, The Bridgespan Group.

Ehrlich, P.R. (2002), Human Natures, Nature Conservation, and Environmental Ethics, BioScience, vol.52, nr.1, pp. 31-43.

Glaser, M. (2006), The social dimension in ecosystem management: strengths and weaknesses of human-nature mind maps, Human Ecology Review, vol.13, nr.2, pp. 122-142.

Grădinaru, G. (2008). Tehnici de analiză statistică a beneficiilor de mediu. ASE Printing House, Bucharest.

Grădinaru, G. (2004). The bases of Environment Statistics. ASE Printing House, Bucharest.

Grădinaru, G., Colibabă, D., Voineagu, V. (2003). Quantitative Methods for Environment Data Analyses. ASE Printing House, Bucharest. 
Hannah, L., Carr, J.L., Lankerani, A. (1994), Human Disturbance and Natural Habitat: a Biome Level Analysis of Global Data Set, Conservation International, Washington DC.

Hezri, A.A., Dovers, S.R., (2006). Sustainability indicators, policy and governance. Issues for ecological economics, Ecological Economics, 60, pp. 86-99.

Lackey, R.T. (1998), Ecosystem management: paradigms and prattle, people and prizes, Renewable Resources Journal, vol.16, nr.1, pp. 8-13.

Layke, C. (2009), Measuring nature's benefits: a preliminary roadmap for improving ecosystem service indicators, World Resources Institute Working Paper, Washington, D.C.

MEA (2005), Millennium ecosystem assessment. Ecosystems and human well-being: scenarios 2, Washington DC, IslandPress.

Negrei, C. (2004). Economia şi politica medilui. ASE Publishing House, Bucharest.

OECD (1993), OECD core set of indicators for environmental performance reviews, Synthesis report by the group on the state of the environment, ENV/EPOC/GEP (93)5/ADD, Paris.

OECD (1997), OECD core set of environmental indicators, Biodiversity and Landscape - draft working paper, Group on the State of the Environment, ENV/EPOC/SE (96)13/REV1, Paris.

OECD (1998), Agriculture and biodiversity, OECD workshop on agri-environmental indicators, COM/AGR/CA/ENV/EPOC (98)79, Paris.

OECD (1999), Environmental indicators for agriculture: methods and results - the stocktaking report greenhouse gases, biodiversity, wildlife habitats, COM/AGR/CA/ENV/EPOC (99)82, OECD, Paris.

OECD Proceedings (2000). "Frameworks to measure sustainable development, An OECD Expert Workshop. 


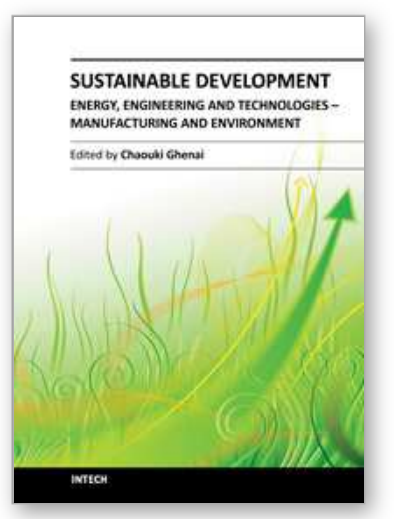

\author{
Sustainable Development - Energy, Engineering and Technologies \\ - Manufacturing and Environment \\ Edited by Prof. Chaouki Ghenai
}

ISBN 978-953-51-0165-9

Hard cover, 264 pages

Publisher InTech

Published online 29, February, 2012

Published in print edition February, 2012

The technological advancement of our civilization has created a consumer society expanding faster than the planet's resources allow, with our resource and energy needs rising exponentially in the past century. Securing the future of the human race will require an improved understanding of the environment as well as of technological solutions, mindsets and behaviors in line with modes of development that the ecosphere of our planet can support. Some experts see the only solution in a global deflation of the currently unsustainable exploitation of resources. However, sustainable development offers an approach that would be practical to fuse with the managerial strategies and assessment tools for policy and decision makers at the regional planning level. Environmentalists, architects, engineers, policy makers and economists will have to work together in order to ensure that planning and development can meet our society's present needs without compromising the security of future generations.

\title{
How to reference
}

In order to correctly reference this scholarly work, feel free to copy and paste the following:

Giani Gradinaru (2012). An Economy-Environment Integrate Statistic System, Sustainable Development Energy, Engineering and Technologies - Manufacturing and Environment, Prof. Chaouki Ghenai (Ed.), ISBN: 978-953-51-0165-9, InTech, Available from: http://www.intechopen.com/books/sustainable-developmentenergy-engineering-and-technologies-manufacturing-and-environment/an-economy-environment-integratedstatistic-system

\section{INTECH}

open science | open minds

\section{InTech Europe}

University Campus STeP Ri

Slavka Krautzeka 83/A

51000 Rijeka, Croatia

Phone: +385 (51) 770447

Fax: +385 (51) 686166

www.intechopen.com

\section{InTech China}

Unit 405, Office Block, Hotel Equatorial Shanghai

No.65, Yan An Road (West), Shanghai, 200040, China

中国上海市延安西路65号上海国际贵都大饭店办公楼 405 单元

Phone: +86-21-62489820

Fax: $+86-21-62489821$ 
(C) 2012 The Author(s). Licensee IntechOpen. This is an open access article distributed under the terms of the Creative Commons Attribution 3.0 License, which permits unrestricted use, distribution, and reproduction in any medium, provided the original work is properly cited. 